UDC 666.32/.36

\title{
Methods to improve the quality of ceramic products
}

Endzhievskaya I.G. ${ }^{1, a}$, Vasilovskaya N.G. ${ }^{2, \mathrm{~b}}$, Gofman O.V. ${ }^{3, \mathrm{c}}$, Klindukh N.Y., d, Kulik V.A. ${ }^{5, \mathrm{e}}$

1, 2, 3,4, 5 RUSSIA, 660041, Krasnojarsk, Siberian Federal University, Svobodnyi pr., 79

a $\underline{\text { icaend@mail.ru, }},{ }^{\mathrm{b}}$ vasng46@mail.ru, ${ }^{\mathrm{c}}$ oksana_slakova@mail.ru, ${ }^{\mathrm{d}}$ NKlind@sfu-kras.ru,

'Vlad1slav96@mail.ru

Keywords: ceramics, dispersion, natural kaolinite, strength, mechanical activation.

Annotation. This article presents the results of experimental studies aimed at improving the physicomechanical properties of effective hollow ceramic stones using various technological methods that will disperse, homogenize and structure the ceramic mixture by introducing industrial waste with high alumina content, dispersed reinforcement, and also mechanical activation of the molding material, accompanied by the fragmentation of clay particles to a colloidal degree of dispersion, allows eliminating the aging process. The main molding characteristics of the investigated mixtures were determined, X-ray phase analysis of ceramic masses and a shard of the control composition was performed and after dispersion, activation modes were worked out, strength characteristics of ceramic samples made of dispersed clay raw materials were determined.

\section{Introduction}

One of the problems of the construction industry is the excessive consumption of energy resources and the depletion of stocks of high-quality raw materials. Currently, the majority of wall materials used in construction do not have the necessary set of properties that correspond to the modern tasks of housing construction. In order to increase the requirements for energy saving and reduce the cost of production, it is necessary to increase the output of multifunctional wall products - at the same time being structural, insulating and facing. Ceramic materials can fully meet these requirements.

At the present stage of development of the construction ceramics industry, attention is focused on improving the technology, improving the quality of products and expanding the range in the direction of producing effective hollow ceramic stones, instead of traditional solid brick. This will not only save raw materials, but also reduce the thickness and weight of external walls without reducing their heat-shielding properties. Switching to efficient and high-tech ceramic products of low average density $-1250-1350 \mathrm{~kg} / \mathrm{m} 3$ or less due to the increase in the size and volume of voids, will reduce the consumption of materials by $1 \mathrm{~m} 2$ of external walls by $20-30 \%$. However, one of the limiting factors of the expansion of the product range is that in many regions there is a significant shortage of high-quality clay raw materials to ensure their high strength and crack resistance.

Enterprises producing ceramic wall products are forced to involve in the production of raw materials with unsatisfactory properties, so the manufacturing technology becomes complicated and there is a need to introduce a significant amount of refractory clay, which allows several adjustments to the composition of the ceramic mixture.

In addition, to improve the technological properties and obtain higher-quality products, sumping is used - curing for a certain time and under certain conditions in order to destroy the natural structure, which leads to disintegration of the aggregated particles into elementary grains, an increase in the specific surface and a deepening of the swelling processes, an increase in the number of bound water, an increase in the plasticity and coherence of clay, an improvement in the molding and drying properties [1,2], the leaching of harmful impurities of soluble salts (su chlorites and chlorides) and others. 
However, in order to save money, many enterprises prefer to work "from the wheels". Therefore, the inclusion of additional mechanical treatment in the technology of wall ceramics will allow us to obtain a homogenous workable homogeneous mass and significantly improve the physical and mechanical properties of products [3]. The more completely destroyed the structure of the clay and the more homogeneous the moldable mass, the higher the quality of the product [4].

At the moment there are several ways to influence the clay mass in order to increase the strength of products. In the study of the South Ural State University (Chelyabinsk), the following methods are used to improve the physicomechanical characteristics: mechanical activation, ultrasound and electromagnetic impulses [5, p.25], which favorably affects the rheological properties of clay suspensions. Russian [6-10] and foreign scientists [11-14] dealt with mechanical activation in ceramic systems. A number of works are devoted to questions of possible ways of modifying ceramic masses [1, 4, 15-17], including using silicon carbide [5-6]. Also known is the experience of improving the quality of ceramic bricks based on dusty loam by introducing metal fibers 18].

Thus, the production of modern ceramic materials, such as hollow ceramic stones, requires improving the quality of the molding material through various technological methods that will allow to homogenize and disperse the ceramic mixture, such as the introduction of various additives, associated industrial products instead of expensive parts of the mixture - refractory clay, as well as improving the processing of raw materials.

In this regard, studies on the use of additional opportunities to improve the quality of clay raw materials in order to obtain effective wall products are highly relevant.

\section{Task formulation}

The study used a number of methods to improve the physicomechanical characteristics of effective hollow ceramic stones:

- introduction to the mixture of additives - industrial waste with a high content of alumina,

- dispersed reinforcement of ceramic mass,

- processing of the molding material in a hydrodynamic dispersant.

The purpose of this work is to improve the properties of the ceramic shard and increase the physicomechanical characteristics of effective ceramic products using various technological methods that will disperse, homogenize and structure the ceramic mixture by introducing additives, as well as mechanoactivating the molding material, followed by crushing the clay particles to a colloidal degree dispersion to eliminate the process of aging.

The studies used low-quality loam of the Kubekovskoye field located in the city of Krasnoyarsk, which identified the main molding properties (Table 1) - plasticity and career moisture, as well as the grain size distribution with the release of three main fractions: clay - with particles less than 5 $\mu \mathrm{m}(0.005 \mathrm{~mm})$, silt powder with a particle size of 5-50 $\mu \mathrm{m}(0.005-0.05) \mathrm{mm}$, sandy with a particle size of $50 \mu \mathrm{m}$ or more $(0.05-2) \mathrm{mm}$ (Table 2$)$.

Table 2. Molding properties of clay raw materials

\begin{tabular}{|c|c|c|c|c|}
\hline $\begin{array}{c}\text { Plasticity } \\
\text { number }\end{array}$ & Group name & $\begin{array}{c}\text { Career } \\
\text { Humidity }\end{array}$ & $\begin{array}{c}\text { Fluidity rate, } \\
\text { IL, DE }\end{array}$ & $\begin{array}{c}\text { Soil classification, GOST } \\
\text { 25100-2011 (paragraphs } \\
\text { B.2.9, B.2.10, B.2.12) }\end{array}$ \\
\hline 9,4 & $\begin{array}{c}\text { Moderately } \\
\text { plastic }\end{array}$ & 19,8 & 0,3 & $\begin{array}{c}\text { Loam }(7<1 \mathrm{p} \leq 17) ; \\
\text { light sandy } \\
(7<1 \mathrm{p} \leq 12, \text { sand } \geq 40) ; \\
\text { refractory } \\
(0,25<1 \mathrm{~L} \leq 0.50)\end{array}$ \\
\hline
\end{tabular}


Table 3. The granulometric composition of the clay raw materials

\begin{tabular}{|c|c|c|c|}
\hline Sample number of the & \multicolumn{3}{|c|}{ The content of fractions, \% wt. } \\
\cline { 2 - 4 } studied raw materials & $\begin{array}{c}\text { Sand particles (1- } \\
0,05) \mathrm{mm}\end{array}$ & $\begin{array}{c}\text { Dusty particles }(0.05- \\
0.005 \mathrm{~mm})\end{array}$ & $\begin{array}{c}\text { Clay particles (less } \\
\text { than 0.005) mm }\end{array}$ \\
\hline 1 & 40,00 & 49,64 & 10,36 \\
\hline 2 & 40,10 & 48,55 & 11,35 \\
\hline
\end{tabular}

According to the research, the clay raw materials from the Kubekovskoye deposit belong to loams and are suitable for making solid brick, but do not fall within the maximum strength values on the grain size distribution diagram of grains, indicating its low quality and, accordingly, a significant correction of the charge is required.

\section{Summary and discussion}

The study used burnt rocks of the Uyarskoye field with a relatively high content of alumina as an additive in the composition of the clay raw materials to improve the drying properties of the raw material and the appearance of the products, which can be classified as low-grade, partially denitrated kaolinite, located under the gliege. The chemical composition of clay raw materials and burning rock (kaolinite) is given in table. 3

Table 3 - The average chemical composition of clay raw materials and burnt rock (kaolinite), $\%$

\begin{tabular}{|l|c|c|c|c|c|c|c|c|c|c|}
\hline \multirow{2}{*}{ Material name } & \multicolumn{10}{|c|}{ Oxide content, } \\
\cline { 2 - 11 } & $\begin{array}{c}\Pi . \Pi . \\
\Pi\end{array}$ & $\mathrm{SiO}_{2}$ & $\mathrm{Al}_{2} \mathrm{O}_{3}$ & $\begin{array}{c}\mathrm{Fe}_{2} \mathrm{O}_{3} \\
+\mathrm{FeO}\end{array}$ & $\mathrm{CaO}$ & $\mathrm{MgO}$ & $\mathrm{SO}_{3}$ & $\mathrm{Na}_{2} \mathrm{O}$ & $\mathrm{K}_{2} \mathrm{O}$ & $\mathrm{TiO}$ \\
\hline $\begin{array}{l}\text { Kubekovsky } \\
\text { loam }\end{array}$ & 8,90 & 58,76 & 14,52 & 5,22 & 6,71 & 1,83 & - & 1,68 & 1,44 & - \\
\hline Natural kaolinite & 7,18 & 65,62 & 19,90 & 2,95 & 1,25 & 1,31 & 0,22 & 0,28 & 0,96 & 0,18 \\
\hline $\begin{array}{l}\text { Metakaolin } \\
\text { (burning at t } \\
\text { 6500C, burning } \\
\text { time 15-20 min.) }\end{array}$ & 1,59 & 69,73 & 20,99 & 3,54 & 1,17 & 1,39 & 0,19 & 0,29 & 1,00 & 0,18 \\
\hline
\end{tabular}

Burnt rock (kaolinite) was used in the charge in an amount of from 5 to $20 \%$ by weight instead of refractory clay from the Kampanovsky deposit to improve the properties and improve the quality of ceramic products based on loam. Optimal values of strength were obtained with the introduction of it in an amount of $15 \%$ (Table 5). The dried samples were annealed in a muffle furnace at a temperature of $950^{\circ} \mathrm{C}$. Their cooling took place with the furnace. Burnt specimens were tested first for bending, and then their halves were compressed.

Studies have also been conducted of the effect of the introduction of disperse reinforcement on the structuring of the ceramic mass and the physicomechanical characteristics of the ceramic shard (Fig. 1). The prospects for using fiber as reinforcing components of ceramic products significantly depend on the resistance of fibers to the effects of high-temperature processing. The composition of 


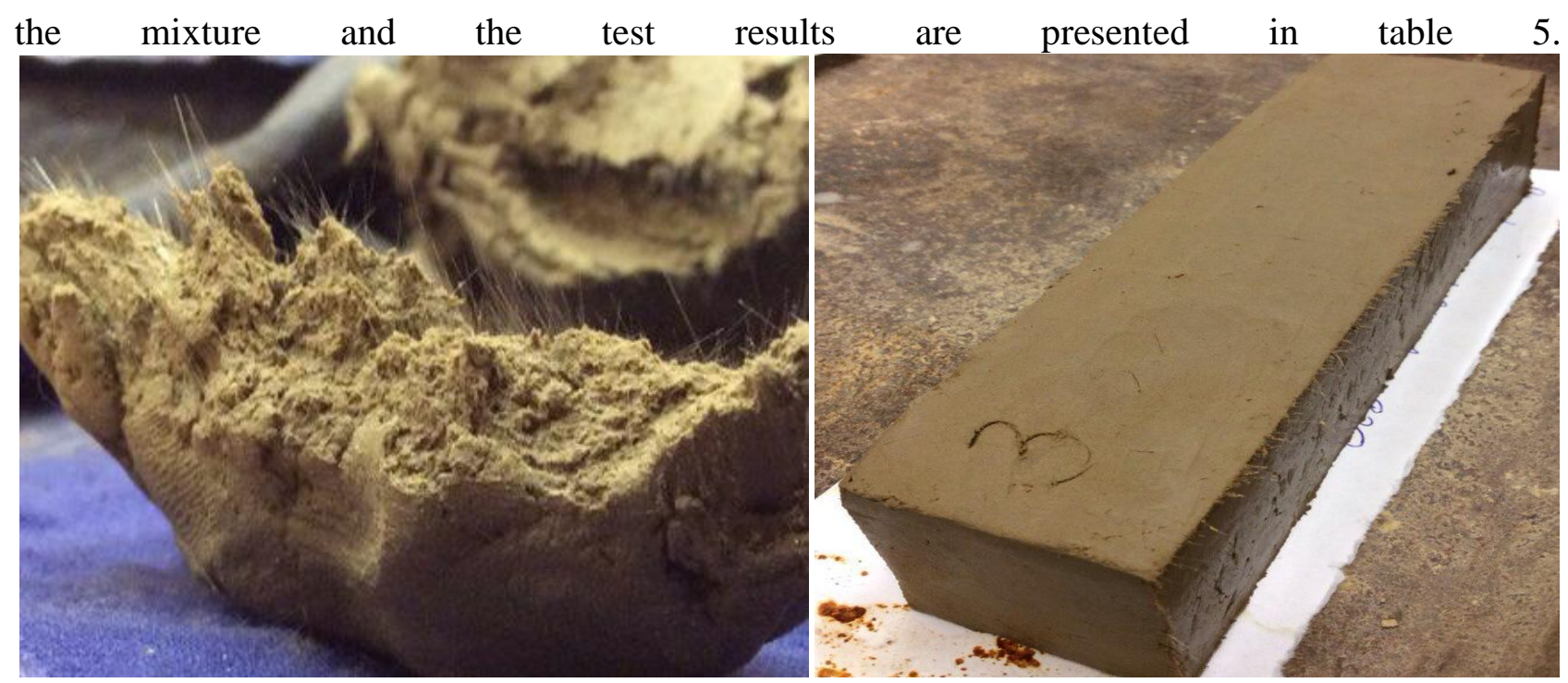

Picture 1. Clay mass with dispersed reinforcement

Table 5. Averaged test results of ceramic samples

\begin{tabular}{|c|c|c|c|c|c|c|c|}
\hline $\begin{array}{c}\text { Types of } \\
\text { additives }\end{array}$ & $\begin{array}{c}\text { Additive } \\
\text { consumption, } \%\end{array}$ & Clay, $\%$ & $\begin{array}{c}\text { Water } \\
, \%\end{array}$ & $\begin{array}{c}\rho, \\
\mathrm{g} / \mathrm{cm}^{3}\end{array}$ & $\begin{array}{c}\text { Compressive } \\
\text { strength, } \\
\mathrm{MPa}\end{array}$ & $\begin{array}{c}\text { Flexural } \\
\text { strength, } \\
\mathrm{MPa}\end{array}$ & $\begin{array}{c}\text { Water } \\
\text { absorption, } \%\end{array}$ \\
\hline- & - & 100 & 25 & 1,80 & 8,30 & 3,20 & 16,95 \\
\hline $\begin{array}{c}\text { Natural } \\
\text { kaolinite }\end{array}$ & 15 & 85 & 25 & 1,74 & 15,30 & 4,79 & 18,29 \\
\hline Metakaolin & 15 & 85 & 25 & 1,76 & 15,95 & 4,90 & 18,00 \\
\hline Basalt fiber & 0,3 & 100 & 25 & 1,67 & 13,79 & 5,59 & 17,80 \\
\hline $\begin{array}{c}\text { Chrysotile } \\
\text { fiber }\end{array}$ & 2,0 & 98 & 25 & 1,60 & 15,85 & 5,33 & 18,13 \\
\hline
\end{tabular}

Thus, optimization of the charge for the production of ceramic products by introducing byproducts of the coal mining industry, such as burned rocks and also disperse reinforcement, can significantly increase the strength not only during compression, but also during bending. A visual observation showed that when basalt fiber is introduced into the ceramic mixture, it does not form hedgehogs and structures the ceramic shard.

Mechanical activation of the clay mass was carried out in a hydrodynamic disperser. The moistened ceramic mass processed in this device is subjected to dispersion and homogenization, which makes it possible to exclude the curing operation from the production process and improves the physicomechanical characteristics of the products.

The optimal modes of operation of the dispersant were tested, in which the clay mass would have sufficient plasticity and uniformity for better moldability of the samples. The activation mode of clay masses changed, which differed in processing time and rotor speed. The properties of clay masses and the strength characteristics of ceramic shards were studied after exposure to various combinations of these modes.

The dried ceramic masses of the control composition and activated in the dispersant were investigated using X-ray phase analysis, the results are shown in Fig.2. The diffraction patterns of the same compositions after firing are shown in fig. 3

When overlaying the diffractograms of the control composition and processed in the dispersant, the following is observed.

The clay contains minerals:

- clayey - kaolinite $(\mathrm{d}=0.385 ; 0.354 ; 0.337 \mathrm{~nm}$, etc.), montmorillonite $(\mathrm{d}=0.447 ; 0.319 ; 0.283$ $\mathrm{nm})$, hydromica $(\mathrm{d}=0.403 ; 0.323 ; 0.284 \mathrm{~nm})$ in an amount of about $34 \%$;

- quartz $(\mathrm{d}=0.425 ; 0.335 \mathrm{~nm}) \approx 21 \%$; 
- feldspars $(\mathrm{d}=0.321 ; 0.299 ; 0.293 \mathrm{~nm}) \approx 15 \%$;

- the rest - impurities in the form of carbonates, oxides and hydroxides of iron, mica, chlorites.

The diffraction maxima of the dispersed ceramic mass are much deeper, which apparently indicates a greater destruction of the natural structure, partial coagulation of clay particles, and an increase in their specific surface.

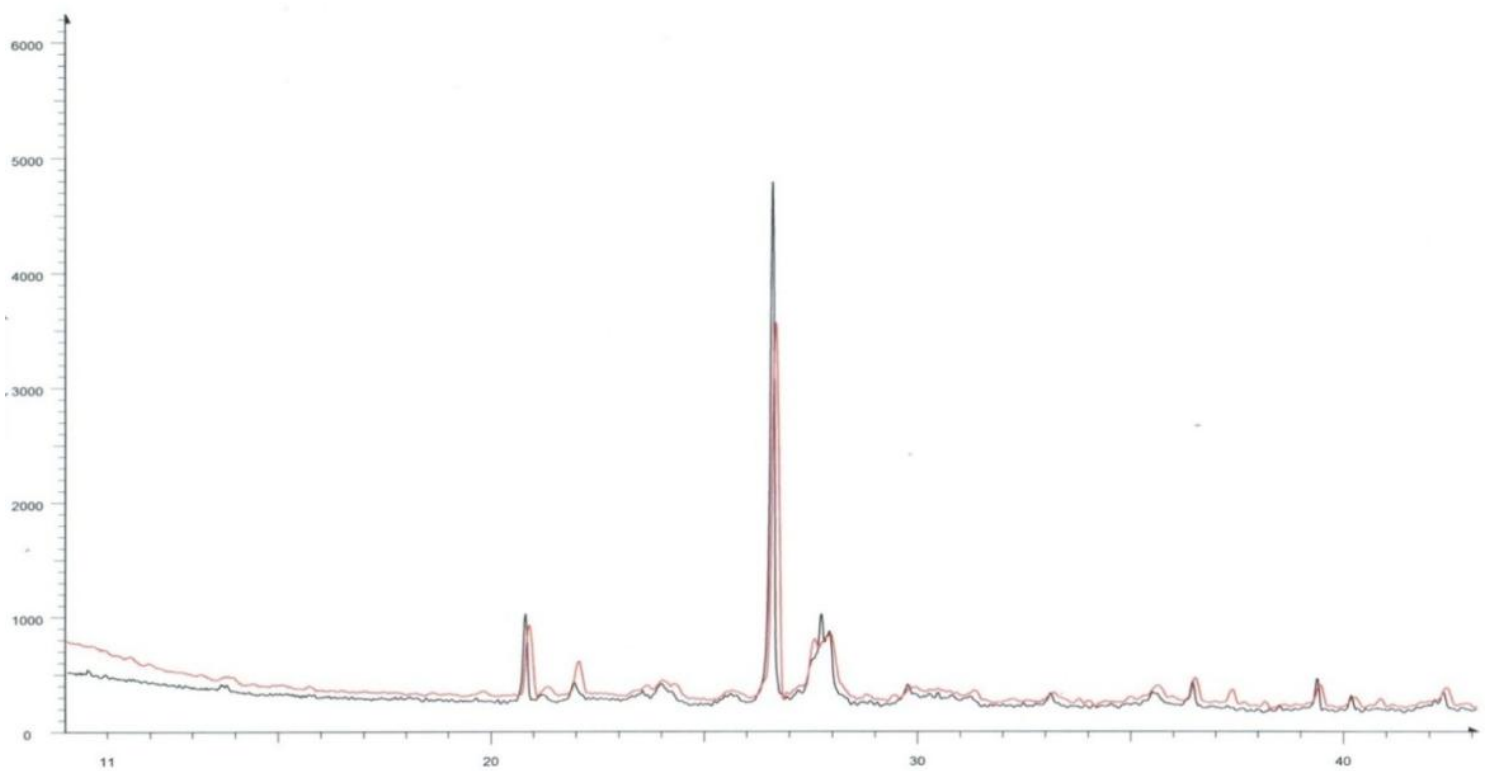

Figure. 2. Diffractograms of ceramic masses: red - control composition; black - composition after dispersion

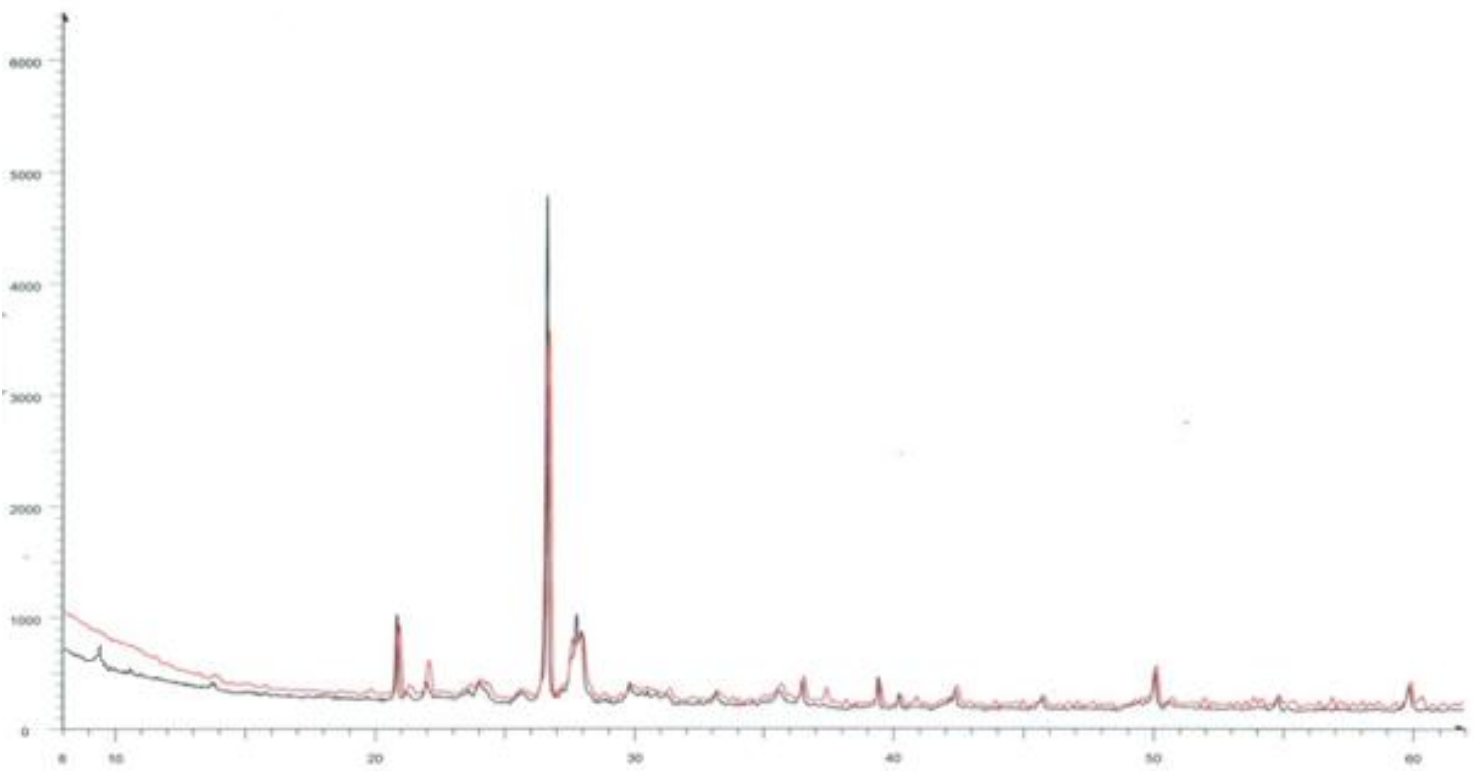

Figure. 3. Diffractograms of ceramic masses after firing: red - control composition; black composition after dispersion

Also on diffractograms (Fig. 3), an increase in the intensity of diffraction maxima and a slight decrease in their number in burnt activated-mass samples are observed in comparison with the control samples, which obviously indicates a larger number of tumors and, possibly, the formation of the mullite-like phase at lower temperatures. These studies are supported by the results of testing the molding properties of ceramic masses and the physicomechanical characteristics of the calcined samples, depending on the duration and speed of mechanical activation (Table 6). 
Table 6. Averaged test results of ceramic samples

\begin{tabular}{|c|c|c|c|c|c|c|c|c|}
\hline \multicolumn{2}{|c|}{ Composition } & \multicolumn{2}{c|}{$\begin{array}{c}\text { Mechanical } \\
\text { Activation Modes }\end{array}$} & \multicolumn{3}{c|}{ Shrinkage, } & \multicolumn{2}{c|}{ Strength, MPa, at } \\
\hline Loam & $\begin{array}{c}\text { Meta } \\
\text { kaolin }\end{array}$ & $\begin{array}{c}\text { Time, } \\
\text { min }\end{array}$ & $\begin{array}{c}\text { Speed, } \\
\text { rpm }\end{array}$ & Aerial & Fire & Total & bend & compression \\
\hline 100 & - & - & - & 6,8 & 1,5 & 12,3 & 3,20 & 8,30 \\
\hline 100 & - & 2 & 3000 & 6,5 & 1,4 & 11,9 & 4,02 & 13,9 \\
\hline 100 & - & 5 & 3000 & 7,9 & 0,2 & 8,1 & 3,21 & 12,0 \\
\hline 100 & - & 2 & 5000 & 7,0 & 1,0 & 8,0 & 3,20 & 11,2 \\
\hline 90 & 10 & 5 & 3000 & 4,6 & 0,6 & 5,2 & 3,60 & 10,8 \\
\hline 90 & 10 & 5 & 5000 & 6,0 & 0,2 & 6,2 & 4,20 & 14,8 \\
\hline 85 & 15 & 5 & 3000 & 5,6 & 0,2 & 5,8 & 4,70 & 15,5 \\
\hline 85 & 15 & 5 & 5000 & 5,6 & 0,2 & 5,8 & 4,80 & 17,89 \\
\hline
\end{tabular}

Analysis of the results showed an increase in the strength characteristics of the samples, from activated clay masses, in comparison with the control composition.

\section{Conclusions}

1) The correspondence of the regularities of the formation of the main technical and operational characteristics of the ceramic material, installed at the stage of laboratory research, was revealed; each of the applied technological methods provides an increase in the strength of the ceramic shard.

2) Optimization of the charge for the production of ceramic products by introducing a by-product of the coal mining industry - low-quality kaolinite located under gliege, as well as disperse reinforcement, can significantly increase the strength not only during compression, but also during bending.

3) The possibility and expediency of dispersion to solve the problem of obtaining strong ceramic products was confirmed. Mechanical activation can successfully replace the long and laborious redistribution of the technological process - curing;

4) The modes of activation of ceramic masses in a production environment need further adjustment.

\section{References}

Reference to the article:

[1] Bogdanov A.N., Abdrakhmanova L.A., Izvestia KGASU, 3, 103-107 (2014)

[2] Akbas, H. Z., Aydin Z., Yilmaz O. \& Turgut S., Effects of ultrasonication and conventional mechanical homogenization processes on the structures and dielectric properties of BaTiO3 ceramics. Ultrason Sonochem, 2017, 34, 873-880 p.

[3] Bolyak V. I., Zubjohin A.P., Yatsenko N.D. Building materials, equipment, technologies of the XXI century,11, 18- 20 (2011)

[4] Bogdanov A.N., Abdrakhmanova L.A., Khozin V.G., High Technologies and Innovations, $1,46-49(2014)$

[5] Smolko V. A., Antoshkina E. G. Electrophysical methods of activation of aqueous suspensions of clay minerals: Chelyabinsk: Vestnik of the South Ural State University. Series: Metallurgy, 30.01.2014.- 24-27 c [ Smolko V. A., Antoshkina E. G. Electrophysical methods of activation of aqueous suspensions of clay minerals: Chelyabinsk: Vestnik of the South Ural State University. Series: Metallurgy, 30.01.2014.- 24-27 p (in Russian)]

[6] Kotlyar, T. A. Influence of SiC on thermophysical and strength properties of siliceous ceramics: dissertation of candidate of physical and mathematical sciences.- Bishkek, 2006.- $144 \mathrm{c}$ [ Kotlyar, T. A. Influence of SiC on thermophysical and strength properties of siliceous ceramics: dissertation of candidate of physical and mathematical sciences.- Bishkek, 2006.- 144 p. (in Russian)] 
[7] Lukhanin M. V., Avakumov E. G., Pavlenko S.I. The role of mechanochemical activation in obtaining refractory ceramics based on mullite and carbide made from secondary mineral resources // Refractories and technical ceramics.2004. №1. C. 32-34.

[8] Mashkin, A. N. Activation of the cement binder in hydrodynamic dispersant and the properties of concrete on its basis: thesis of candidate of technical sciences.- Novosibirsk, 2009.152 c [ Mashkin, A. N. Activation of the cement binder in hydrodynamic dispersant and the properties of concrete on its basis : thesis of candidate of technical sciences.- Novosibirsk, 2009.$152 \mathrm{p}$ (in Russian)]

[9] Ovchinnikov, P. F., Mikhailov N. V., Kruglitsky N. N., Rheology of thixotropic systems, Kiev: Naukova Dumka, 1972. - 120 c [ Ovchinnikov, P. F., Mikhailov N. V., Kruglitsky N. N., Rheology of thixotropic systems, Kiev: Naukova Dumka, 1972. - 120 p. (in Russian)]

[10] Pishchenko L. I., Bulgakov B. B., Subach A. A., Petrov B. Yu., Monyatovsky V. V. Cavitation mixer; Pat. Doc. 1173596 - N 3642436/26, stat. 29.07.93., publ. 20.09.97. [ Pishchenko L. I., Bulgakov B. B., Subach A. A., Petrov B. Yu., Monyatovsky V. V. Cavitation mixer; Pat. Doc. 1173596, Kady International - N 3642436/26, stat. 29.07.93., publ. 20.09.97. (in Russian)]

[11] Akbas, H. Z., Aydin Z., Yilmaz O. \& Turgut S., Effects of ultrasonication and conventional mechanical homogenization processes on the structures and dielectric properties of BaTiO3 ceramics. Ultrason Sonochem, 2017, 34, 873-880 p.

[12] Chen, D., L. K. Weavers \& H. W. Walker Ultrasonic control of ceramic membrane fouling by particles: effect of ultrasonic factors. Ultrason Sonochem, 2006, 13, 379-87 p.

[13] Tohmpson L.H. Sonochemistry: Science and engineering. Ind. and Eng. Chem. Res. 1999. - Vol. 38. - N 4. - P. 1215-1249. - ISSN 0888-5885

[14] Le Clair M.L. Method and apparatus for producing liquid suspensions of finely divided matter; Pat. Doc 5522553. Kady International - N 314817, stat. 29.09.94., publ 04.06.96.

[15] Vakulova T. V. Clay. Features of structure and methods of research. Tomsk: Publ. TPU, 1998.-122 c [ Vakulova T. V. Clay. Features of structure and methods of research. Tomsk: Publ. TPU, 1998.-122 p. (in Russian)]

[16] Zubrilov S. P. Comparison of various mechanisms of "cavitation". physical chemistry 2000. - T. 74. - N 9. - C. 1700-1701 [ Zubrilov S. P. Comparison of various mechanisms of "cavitation". physical chemistry 2000. - T. 74. - N 9. - C. 1700-1701 p. (in Russian)]

[17] Efimov A. I., Zhukova E. M., Varlamov V. P., Effectiveness of mineralizers. -1984. № 7. - C. 24-25 [ Efimov A. I., Zhukova E. M., Varlamov V. P., Effectiveness of mineralizers. -1984. No. 7. - Pp. 24-25 p. (in Russian)]

[18] Sharavin, J. A. Particulate-reinforced ceramic brick of silty loam with a decorative powder-polymer coating. abstract. dis. for competition of a scientific degree for a candidate of tech. sciences, Novosibirsk, 2010.-10 c. [ Sharavin, J. A. Particulate-reinforced ceramic brick of silty loam with a decorative powder-polymer coating. abstract. dis. for competition of a scientific degree for a candidate of tech. sciences, Novosibirsk, 2010.-10 (in Russian)] 